\title{
A Research on the Integrated Planning of the Tour Guides' Career Considered from the Tour Guides and the Interested Parties
}

\author{
Zhao-Xi ZENG ${ }^{1, a,{ }^{*}}$ \\ ${ }^{1}$ Tourism Management Department, Jinan Vocational College, Jinan, 250103, China \\ a13616418621@163.com \\ ${ }^{*}$ Corresponding author
}

\begin{abstract}
Keywords: Tour Guides' Career Status; Career Planning; Integrated Planning of the Tour Guides' Career.
\end{abstract}

\begin{abstract}
The tour guides' team in China is developing and expanding continuously, but their professional prospects are not optimistic. The important reason is short of proper career planning. The tour guides' career should be planned from the tour guides themselves and their interested parties: their educated tourism college, travel agency and tourism administration. The planning from each party should be integrated. The career planning is like a running train which cannot run toward a destination unless its different parties are integrated into an entirety. Therefore, in planning the tour guides' career, there should be a proper docking or a part of overlapping if necessary between the tourism college and the travel agency. Meanwhile, the main body of career planning - the tour guides, should cooperate with them, and the tourism administration should provide timely guidance and policy supports. It is not until the planning has integrated the four parties mentioned above that result in the optimistic prospect of tour guides' career.
\end{abstract}

\section{Introduction}

"A male worries about finding the wrong job, while a female worries about marrying the wrong guy.” Analyzed dialectically, the Chinese saying tells us the importance of career choice to Chinese persons in the past. At present, the employment situation is more austere, it is widely believed that persons are very difficult to find a life-long job which is to their hearts' desire. Thus, career planning is necessary. "Career" refers to a person's life-long working experience, particularly the entire process of changing his/her professions or positions and achieving his/her dream(s). "Planning" refers to designing in detail and realizing one's individual reasonable career. "Career planning” refers to a person's expectation and planning in his/her life, including his/her study, work, daily life, etc. Work is the most important among them.

At present, China's tourism industry is in flourishing stage, the tour guides' team is continually developing. It boasts an "Army of One Million Persons". The tour guides are the representatives of a country's or region's tourism industry, but the tour guides' professional prospects in China are not optimistic. (Juan Liu and Junjie Zhang, 2011) They feature getting the job enthusiastically at the beginning, getting an unstable income, low quality as a whole, short duration of stay for the job, etc. Behind the thriving tourist market breeds a "thriving” but unstable tour guides' team. One of the important reasons among them is short of reasonable tour guides' career planning. But, the tour guides who serve the tourists lie in the tail end of service chain of the tourism products. The power to make the decisions of service quality is not in the hands of the tour guides. It is very difficult for the tour guides to achieve their goals by planning themselves the career. The tour guides' career should be planned from the tour guides themselves and their interested parties: their educated tourism college, travel agency and tourism administration. And the planning from each party should be integrated into an entirety. (Please see Fig. 1) 


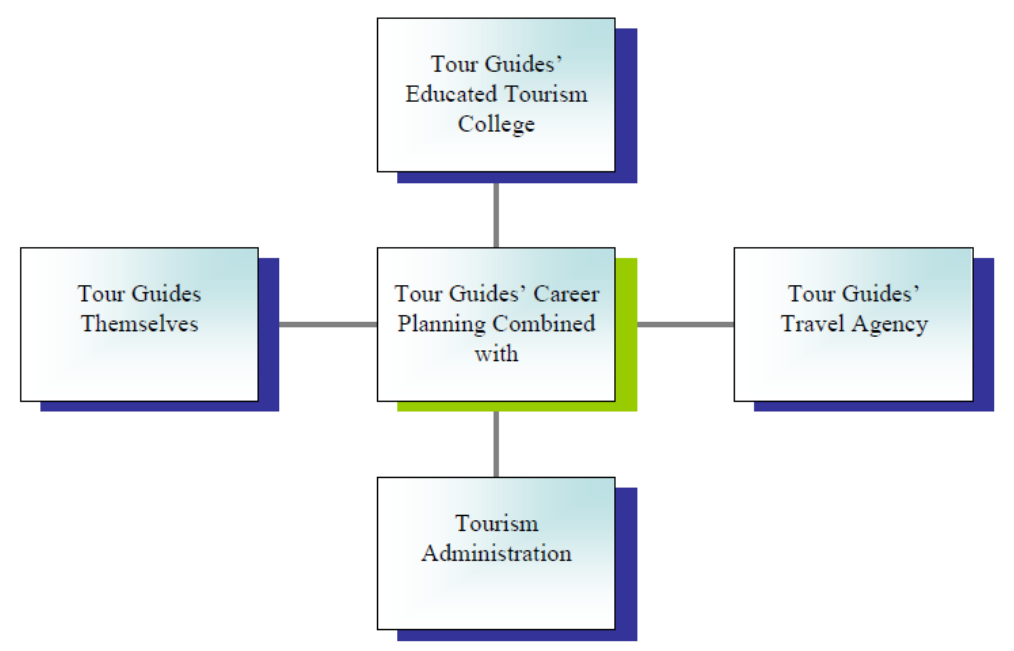

Fig.1. The four parties related with the tour guides’ career planning

\section{Planning the Tour Guides’ Career from the Party of Tourism College}

Entering into the 21st century with the popularization of China's vocational education, the higher vocational colleges and the secondary vocational schools have become the dominated institutions which the tour guides get their education before entering the field of tour guiding. According to recent years' statistics of the examinees of the tour guides' qualification test in Shandong Province, $70 \%$ of them have a background of tourism education, and based on this, more than $80 \%$ even have the higher vocational education background. (Zhaoxi Zeng and Qintao Wang, 2011) Therefore, the tourism schools (departments) in higher vocational colleges should pay special attention to the students' tour guiding career planning. They should correctly guide them to be familiar with the job of tour guiding, and have a deep love for it. The tourism schools (departments) should formulate the reasonable personnel cultivating program, position accurately, cultivate the graduates who have clear career planning, wide range of knowledge, good skills and perfect quality so that a solid foundation can be laid for the formation and development of their career planning.

In recent years, with the expansion of new students' enrollments, the whole quality of freshmen in the higher tourism vocational colleges is lowering too. The students themselves show that they don't have clear aims of learning, positive attitudes of learning, and the spirits of hard working, and sometimes even show that they have grandiose aims but puny abilities. Those students registering the tourism colleges and majoring in tourism (tour guide) courses either just for curiosity, not really for their career, or forced by their parents as they are anything but interested in tourism, let alone the career planning. In view of this situation, the tourism college should establish a tour guide teaching team which has rich tourism knowledge, high tour guiding skills and abundant practical experiences because those excellent teachers can fully mobilize the students' learning enthusiasm, then help them properly plan their career. Furthermore, the teaching and training facilities in the college and the deep cooperation with the travel agencies play a crucial part to the formation of students' career planning, too.

\section{Planning the Tour Guides' Career from the Party of Tourism Administration}

In 1989, since the beginning of China's tour guide qualification test started, the test has been carried through year after year normally. However, the tour guides' grade examination is still experiencing ups and downs. Up to now, except the recovery of intermediate and advanced tour guide examinations, the supreme grade tour guide examination is still in the process of research. Furthermore, the different grades of tour guide have not been recognized by the national personnel and labor department as a technical post. The imperfection of tour guide examination system badly influences the enthusiasm of tour guides' grade examination. And that is not all, the tour guides' pre-post training and their training for annual authorization held by the department concerned 
become the mere formalities, which produce the negative influences on the tour guides; In the process of travel agency's system reform, the tour guides' social status has been declining. They were government workers before 1980s, and the foreign affair reception personnel after it. But they became the enterprise's employees in 1990s. Up to the $21^{\text {st }}$ century, most of them were successively stripped off from the travel agency's staff, and became the "freelancers" due to the vicious competitions which lead to low profits in the travel agencies.

Behind the prosperous development of China's tourism industry is a tourist market which needs to be mature. When the governments at all levels are promoting marketization of tourism, they should offer relevant policy supports and profession guidance for the tour guides instead of simply pushing them into the market. For example, they can set up a systematic entry and exit mechanism for the tour guides, perfect tour guide grade examination system and/or technical post promoting system, establish flexible and reasonable tour guide training system, salary security system and incentive system according to the professional characteristics and the job's demand of the tour guides.

\section{Planning the Tour Guides' Career from the Party of Tour Guides Themselves}

In recent years, the persons who passed the tour guide qualification test and are engaging in tour guiding services are mostly the graduates from the higher tourism vocational colleges. But they quickly switch to another job after finishing their tour guide internship. Besides the factors of hard work and unstable income, etc., the most important factor is that they have no career planning at all. Although in our life time, we cannot probably set a very clear and correct goal at the very beginning, and finish our career planning because of the variation of each factor, however, the tour guides themselves can subdivide the career into several stages, and plan in advance for each stage. We can divide the tour guides' career into four stages according to the stages of life development.

\section{Stage One: the Germination Stage of Tour Guides' Career.}

The germination stage refers to the period before work, mainly indicates the schooling stage. It is also called the exploration stage. In this stage, students should understand the educational objectives and the post positioning of the professionals, learn professional knowledge and skills seriously, frequently contact and know more about the travel agencies and other relevant enterprises with the help from the college and their teachers. They themselves should understand "what to do", "what can be done” and "what should be done”. (Lijing Wang, 2011) After passing the tour guide qualification test, they should practice in the travel agency during their summer and winter holidays to accumulate working experiences, which can lay a solid foundation for the future internship and employment.

\section{Stage Two: the Formative Stage of Tour Guides' Career.}

After two years' schooling and one year internship of tour guiding service, the students have a comprehensive understanding to the career of tour guide. If the students decide to choose "tour guiding" as their job, they have to choose the travel agency which is fit for them. And the location (the city), the scope of the business, the scale, the operation philosophy, the management mode and the salary system, etc. of the travel agency are necessary to be taken into account when they make their decisions. Then they should devote themselves to the tour guiding service on a firm footing, always learn from the excellent tour guides, learn from the senior tour guides, and be loyal to the travel agency. They also should accumulate the tour guiding service experiences so that they can become the excellent tour guides expected by the travel agency as soon as possible. Each tour guide's formative stage is about 1-3 years according to the difference of growing environment and their own conditions.

\section{Stage Three: the Development Stage of Tour Guides' Career.}

After weathering through the difficult formative stage, the tour guides make big progress on all sides. Thus they enter into the steady development stage. During this period, the tour guides pay more attention to their own reputations and images, therefore, they think highly of the service quality, 
income and social status, etc. But their values are not confined to those aspects, they should take advantage of their superiority to help other tour guides, to do more for their travel agency and the society, for example, training new tour guides, giving advice and suggestions to the tour guides' management and the new product development of the travel agency, doing some publicity for their own travel agency or the local tourism industry. The development stage of the tour guides' career is the golden age of the tour guides. Once the tour guides enter into this period, their careers can last for more than 10 years.

\section{Stage Four: the Degenerating Stage of Tour Guides' Career.}

Due to their health or family affairs, the tour guides enter into the degenerating stage after devoting themselves to the tour guiding services for a long time. Some of them work at the rear service offices, manage a department or train other employees in the travel agency, while some other tour guides are transferred to the educational institutions to teach students or to do researches, and "tour guiding service” becomes their part-time job. They usually don't abandon their jobs that they ever had deep love for. They always summarize their experiences, and pass them on to their students (apprentices), encourage their students (apprentices) to proceed to their careers, or compile their valuable experiences into books and/or form papers to help more tour guides.

\section{Planning the Tour Guides' Career from the Party of Travel Agency}

Travel agencies are the major enterprises that the tour guides get their jobs. At present, the situations of "weak", "small”, "loose” exist extensively in the travel agencies of China. Many travel agencies' development planning is not well organized, let alone helping their staff, especially help the tour guides plan the careers. But, in order to realize thorough improvement of the travel agencies' images, they are sure to carry through a scientific planning to their own operating management, and put the staff's career planning (including the tour guides' planning) into the integrated planning of the enterprises, take the staff as the human capital which can be managed together with other capitals. They should help the tour guides understand their own career anchors, development goals and the enterprise's management objectives, develop at the same pace with the enterprise's development, share the success and failures with the enterprise, strengthen the tour guides' receptivity to the career and loyalty to the travel agency. Only by doing so can the travel agencies realize their healthy and sustainable development.

\section{The Integrated Planning of the Tour Guides' Career}

In the previous paragraphs, the tour guides' career planning has been discussed from different parties. However, it is not the purpose of the planning, it is the important means of realizing the tour guides' career, and each planning must be coordinated and unified to drive the career to a consistent development direction. Hence the integrated planning of tour guides' career from different parties is needed. If we take the tour guides' career as a running train, the tour guides resemble the "compartments", the travel agencies resemble the "locomotives", the tourism colleges resemble the "wheels", and the governments concerned resemble the "railroad tracks". All the parties must be integrated to form a resultant force, and to run toward the same destination. (Please see Fig. 2)

Firstly, as the "wheels", the tourism colleges should educate the students who will be the qualified tour guides. That is to say, the "wheels" should be equipped so that the "train" can "run".

Secondly, as the "compartments", the tour guides themselves should form a rough profile of the tour guides' career in the educated period by studying the necessary knowledge and skills according to the tourism college's requirement, participating the tour guiding internship, and looking deeply into the travel agency's businesses and the job of tour guiding. As the "wheels", the tourism colleges should teach the students wholeheartedly the tourism knowledge and skills required for the job of tour guiding according to the tourism industrial standard and the tourist market demand, put the "wheels" under the "compartments", and tell them how to operate effectively. 
Thirdly, as the "locomotives", the travel agencies should properly start the engines, pull the "compartments" to run toward the destination. A travel agency with scientific planning and clear development goal can always change the "train" from a "temporary train" to a "regular train", from a "slow train” to an "express train”, a "bullet train”, or even a "high-speed rail train”.

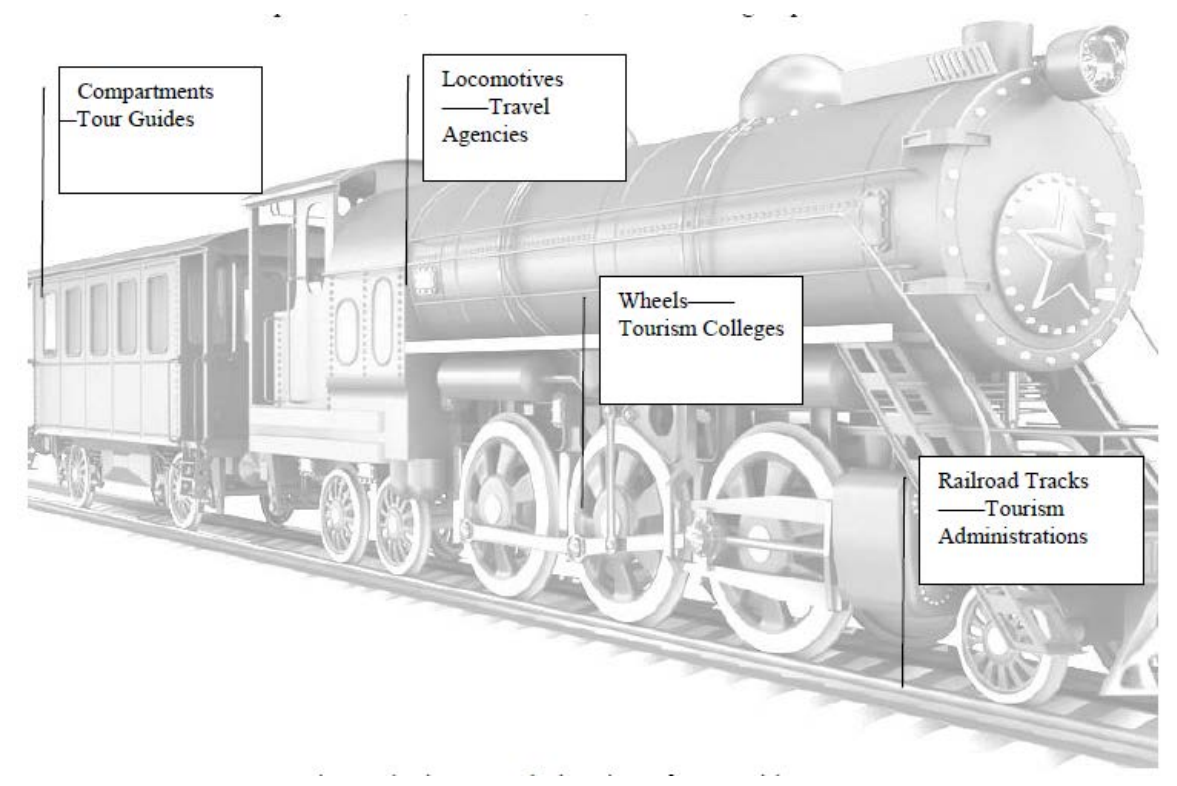

Fig.2. The integrated planning of tour guides’ career

At last, as the "railroad tracks", the governments concerned should "lay the railroad tracks" well to let the "train" have specific driving direction. They should maintain the "railroad tracks" and build new ones if necessary to ensure that the tour guides' career and the travel agency's management have a healthy and speedy development according to the set planning.

\section{Conclusion}

In conclusion, in planning the tour guides' career, there should be a proper docking or a part of overlapping if necessary between the tourism colleges and the travel agencies. The travel agencies should properly get involved in the students' career planning before their graduation, while the tourism colleges should properly extend the chain of career planning after the students' graduation, and the main body of planning - the tour guides should positively cooperate with them. At the same time, the governments concerned should provide timely guidance and policy supports. It is not until the planning has integrated the four parties above that result in the optimistic prospect of tour guide's career.

\section{Acknowledgement}

Thanks to the three persons who helped make the paper complete:

Mei Liu, Vice-chairman of Shandong Travel Association Tour Guide Branch, who offered us a large number of information about the tour guides' status of career planning, and gave us a kind direction on the research; Mingchi Zhang, Director of the Personnel Department of Shandong Tourism Administration, who provided us with the statistical figures of the tour guides' qualification test in Shandong Province for the recent years; and Hong Huang, a section chief in Jinan Tourism Information Center, who helped us find much valuable information about Jinan tour guides' real living conditions. 


\section{References}

[1] Juan Liu and Juanjie Zhang, A Discussion on Tour Guides' Career Planning, Cooperative Economy and Science, 13, 49-50, 2011. (In Chinese)

[2] Zhaoxi Zeng and Qintao Wang, A Research on the Necessary Local Guiding Knowledge for the Higher Tourism College's Students in Shandong Province, Journal of Jinan Vocational College, 05, 47-51, 2011. (In Chinese)

[3] Lijing Wang, How to Help Students Do Their Career Planning Well, Vocational Technology, 03, 59, 2011. (In Chinese)

[4] Zhaoxi Zeng, An Analysis on the Current Situation and Development Proposals of the Higher Tourism Vocational Education in Shandong Province, China Science and Technology Information, 15, 301+307, 2009. (In Chinese)

[5] Qilun Wu, How to Proceed to Career Planning, Career Development, Z3, 26-27, 2011. (In Chinese) 